\title{
Behavior of BFRP bars subjected to dynamic impact loads
}

\author{
Farid Abed $^{1,2^{*}}$, Akrum Abdul-Latif ${ }^{3,4}$, and Zin Mahaini ${ }^{1}$ \\ ${ }^{1}$ Department of Civil Engineering, American University of Sharjah, Sharjah 26666, UAE \\ ${ }^{2}$ Material Science and Engineering Institute, American University of Sharjah, Sharjah 26666, UAE \\ ${ }^{3}$ Laboratoire Quartz, Supméca, 3, rue Fernand Hainaut, 93407 St Ouen CEDEX, France \\ ${ }^{4}$ Université Paris 8, IUT de Tremblay, 93290 Tremblay-en-France, France
}

\begin{abstract}
Fiber Reinforced Polymer (FRP) bars are deemed to be one of the best solutions to the corrosion dilemma associated with steel reinforcement. This paper presents an experimental study on the behavior of Basalt FRP bars subjected to impact loading. Dynamic tests were conducted on eighteen BFRP bars of $17 \mathrm{~mm}$ and $20 \mathrm{~mm}$ diameters (B17 and B20) using the drop hammer test procedure. Different loading rates were achieved through varying the weight of mass and height of fall. The paper evaluated the maximum stresses attained by the BFRP bars at various loading rates. As the loading rate increased, the B20 bars reported a higher strength value. However, the B17 bars showed a drop in the strength with the increase of the loading rate, which requires further investigation. The crushing was observed to be most prominent in the top part of the bars where the bars exhibited a conical shape after failure.
\end{abstract}

\section{Introduction}

Over the last few decades, FRP reinforcement gained attention as a viable alternative to steel bars in concrete structures. The success of the FRP bars is primarily related to their several advantages such as corrosion resistance, high strength, low weight, and magnetic transparency. Numerous studies, available in the literature, address different aspects of the composite reinforcement. Extensive research was carried out to investigate the bond properties of FRP bars [1-3] and examine the flexural and shear performance of concrete structural elements reinforced with FRP bars [4-7]. Nevertheless, FRP bars have been wellestablished as tensile reinforcement in replacement of steel. However, codes do not recommend the application of FRP bars in compression due to lack of research on their compressive properties. For instance, the American and Canadian guidelines for designing FRP reinforced concrete structures advise the designer to disregard the contribution of FRP bars in compression [8,9]. Recently, several studies aimed to evaluate the compressive response of FRP bars, which led towards more tolerance for the use of FRP bars under compression. A comprehensive review by Elmessalami, El Refai, and Abed [10] on FRP reinforced columns showed that FRP bars have considerable contribution under axial compressive loads.

Furthermore, Khorramian and Sadeghian [11] proposed a new method to test Glass FRP (GFRP) bars in compression. The goal was to develop a standardized test that eliminates 
issues such as buckling of the GFRP bars and deliver reliable results. Steel caps, located at each end of the specimen bar, provided a gripping effect to prevent premature failure of the bar. The preparation of the specimen consisted of attaching the steel caps, adjusting the alignment of each bar and installing strain gauges at the middle of the bars. A mechanical testing machine crushed the bars at a rate of $0.5 \mathrm{~mm} / \mathrm{min}$. Analysis of the results showed that the elastic modulus of the GFRP bars in tension and compression is almost the same. The compressive to tensile ratios ranged from 0.55 to 0.99 , which proves that the role of GFRP bars in compression is not negligible.

An investigation by Khan, Sheikh, and Hadi [12] reported on the tensile and compressive characteristics of Glass and Carbon FRP (GFRP and CFRP) bars. For the compression tests, $80 \mathrm{~mm}$ long GFRP specimens and $60 \mathrm{~mm}$ long CFRP specimens were tested in a Universal Testing Machine (UTM) at a loading rate of $1.0-1.3 \mathrm{~mm} / \mathrm{min}$. The bar sizes were $15 \mathrm{~mm}$ and $15.9 \mathrm{~mm}$ in diameter for the GFRP and CFRP bars respectively. The values of the strength and elastic modulus of the FRP bars were determined to be 1.67 and 1.59 times greater in tension than in compression. Similarly, Deitz, Harik, and Gesund [13] evaluated the compressive behavior of GFRP rebars with varying unbraced lengths. The study concluded that there is a link between the different failure modes and the unbraced length of the specimen. The authors noted that for GFRP bars in columns, the failure was most likely to occur due to crushing of the rebars and that the compressive strength was almost half of the tensile strength. The modulus of elasticity in tension and compression was very similar.

In another study, Bruun [14] examined the relationship between the unbraced lengths of GFRP bars and their compressive strength. By applying a loading rate of $100 \mathrm{MPa} / \mathrm{min}$, Bruun recorded the compressive strength for 34 specimen bars with lengths varying from 50 $\mathrm{mm}$ to $600 \mathrm{~mm}$. He found that GFRP bars with unbraced lengths below $230 \mathrm{~mm}$ failed at an axial load of $730 \mathrm{MPa}$ and estimated the elastic modulus as $60 \mathrm{GPa}$. The compressive strength had an inverse relation with the unbraced length of the bars. Moreover, Thiyagarajan, Pavalan, and Sivagamasundari [15] investigated the mechanical characteristics of BFRP bars. The experimental program included tensile, compressive, and short beam shear tests. The results showed the value of the compressive strength of the BFRP bars to be $50 \%$ of the value of the tensile strength. Also, the compressive strength of the BFRP bars varied at reduced amounts with the increase in the bar size.

On the other hand, there were some studies on the performance of concrete members reinforced with FRP bars under compression. Tobbi, Farghaly, and Benmokrane [16] tested eight concrete columns, of which five reinforced with GFRP bars, under axial compressive loads. The conclusions drawn were that the strength reduction factor used for steel-reinforced columns $(0.85)$ is also applicable for GFRP reinforced columns. The GFRP contribution to the total capacity of the column (10\%) was very similar to that of steel $(12 \%)$. Thus, this shows that GFRP bars can be a substitute reinforcement to steel in columns. Likewise, Choo, Harik, and Gesund [17] examined the response of rectangular columns reinforced with FRP bars subjected to axial loads. The paper noted that there is an understatement by codes on the role of FRP bars in compression.

Despite the advancements in the field of the fiber-reinforced polymers, there is insufficient research on the dynamic properties of FRP bars. Goldston, Remennikov, and Sheikh [18] studied the response of GFRP reinforced concrete beams to static and impact loading. The authors implemented the drop hammer test procedure to conduct dynamic tests. They observed that the controlling failure mode for beams under impact loads is the shear plug, which needs to be taken into account when designing beams for impact loading conditions. Another study by Roudsari et al. [19] opted for analytical methods to explore the behavior of FRP reinforced beams under impact loads. The study used a simulation of the drop hammer procedure, which represent impact loading conditions. Experimental results 
showed that CFRP bars enhanced beam's capacity, whereas GFRP bars enhanced beam's ductility under impact loads.

The objective of this paper is to report on the response of BFRP bars subjected to impact loads. The main variables were the bar diameter and rate of loading. The results were analyzed and discussed in terms of the ultimate strength of the bars.

\section{Experimental Program}

An experimental program was conducted to analyze the dynamic performance of FRP bars. This section describes the details of the specimens, test set-up, and instrumentation.

\subsection{Test Matrix}

In this study, the tests included 15 bars tested under impact loads. The bar details and results, in terms of maximum load and stress, under dynamic loading, are summarized in table 1- 3. The BFRP bars were divided into two groups, B0 and B1 referring to the old and new batch, respectively. The different parameters examined in this study were the bar diameter, and rate of loading. The notation identifies the batch of the bar and nominal diameter. For example, the ID (B0-D20) designates an old batch BFRP bar with a $20 \mathrm{~mm}$ diameter. The results listed in tables $1-3$ show that the maximum stress achieved under dynamic loads varies from 170.4 $\mathrm{MPa}$ to $419.8 \mathrm{MPa}$.

Table 1. Details and Dynamic Results of B0-D20.

\begin{tabular}{|c|c|c|c|c|c|c|}
\hline $\begin{array}{c}\text { Loading } \\
\text { Rate } \\
(1 / \mathrm{s})\end{array}$ & $\begin{array}{l}\text { Specimen } \\
\text { Number }\end{array}$ & $\begin{array}{c}\text { Length } \\
(\mathrm{mm})\end{array}$ & $\begin{array}{c}\text { Diameter } \\
(\mathrm{mm})\end{array}$ & $\begin{array}{c}\text { Impact } \\
\text { Energy } \\
(\mathrm{J})\end{array}$ & $\begin{array}{c}\text { Maximum } \\
\text { Load } \\
(\mathrm{kN})\end{array}$ & $\begin{array}{c}\text { Maximum } \\
\text { Stress } \\
(\mathrm{MPa})\end{array}$ \\
\hline \multirow{4}{*}{195} & S1 & 40 & 20.7 & 809.3 & 141.2 & 419.8 \\
\hline & S2 & 40 & 20.7 & 809.3 & 129.0 & 383.3 \\
\hline & & & & $\begin{array}{l}\text { Average } \\
\text { Standard }\end{array}$ & 135.1 & 401.6 \\
\hline & & & & Deviation & 6.1 & 18.3 \\
\hline \multirow{4}{*}{217} & S3 & 40 & 20.7 & 808.3 & 416.5 & 140.2 \\
\hline & S4 & 40 & 20.7 & 808.3 & 596.2 & 200.6 \\
\hline & & & & $\begin{array}{l}\text { Average } \\
\text { Standard }\end{array}$ & 506.4 & 170.4 \\
\hline & & & & Deviation & 89.9 & 30.2 \\
\hline
\end{tabular}


Table 2. Details and Dynamic Results of B1-D17.

\begin{tabular}{|c|c|c|c|c|c|c|}
\hline $\begin{array}{c}\text { Loadin } \\
\text { g Rate } \\
(1 / \mathrm{s})\end{array}$ & $\begin{array}{c}\text { Specimen } \\
\text { Number }\end{array}$ & $\begin{array}{l}\text { Length } \\
(\mathrm{mm})\end{array}$ & $\begin{array}{l}\text { Diameter } \\
(\mathrm{mm})\end{array}$ & $\begin{array}{c}\text { Impact } \\
\text { Energy } \\
(\mathrm{J})\end{array}$ & $\begin{array}{c}\text { Maximum } \\
\text { Load } \\
(\mathrm{kN})\end{array}$ & $\begin{array}{c}\text { Maximum } \\
\text { Stress } \\
(\mathrm{MPa})\end{array}$ \\
\hline \multirow{5}{*}{175} & $\mathrm{~S} 1$ & 36 & 17.1 & 468.9 & 87.3 & 380.0 \\
\hline & S2 & 36 & 17.1 & 468.9 & 99.0 & 431.1 \\
\hline & S3 & 36 & 17.1 & 468.9 & 102.9 & 448.2 \\
\hline & & & & $\begin{array}{l}\text { Average } \\
\text { Standard }\end{array}$ & 96.4 & 419.8 \\
\hline & & & & Deviation & 6.6 & 29.0 \\
\hline \multirow{4}{*}{214} & S4 & 36 & 17.1 & 493.0 & 45.8 & 199.3 \\
\hline & S5 & 36 & 17.1 & 493.0 & 44.5 & 193.9 \\
\hline & & & & $\begin{array}{l}\text { Average } \\
\text { Standard }\end{array}$ & 45.2 & 196.6 \\
\hline & & & & Deviation & 0.6 & 2.7 \\
\hline
\end{tabular}

Table 3. Details and Dynamic Results of B1-D20.

\begin{tabular}{|c|c|c|c|c|c|c|}
\hline $\begin{array}{c}\text { Loading } \\
\text { Rate } \\
(1 / \mathrm{s})\end{array}$ & $\begin{array}{c}\text { Specimen } \\
\text { Number }\end{array}$ & $\begin{array}{l}\text { Length } \\
(\mathrm{mm})\end{array}$ & $\begin{array}{l}\text { Diameter } \\
(\mathrm{mm})\end{array}$ & $\begin{array}{c}\text { Impact } \\
\text { Energy } \\
(\mathrm{J})\end{array}$ & $\begin{array}{c}\text { Maximum } \\
\text { Load } \\
(\mathrm{kN})\end{array}$ & $\begin{array}{c}\text { Maximum } \\
\text { Stress } \\
(\mathrm{MPa})\end{array}$ \\
\hline \multirow{5}{*}{191} & S1 & 40 & 20.6 & 903.5 & 101.3 & 313.1 \\
\hline & S2 & 40 & 20.6 & 903.5 & 114.7 & 344.1 \\
\hline & S3 & 40 & 20.6 & 903.5 & 141.6 & 424.9 \\
\hline & & & & $\begin{array}{l}\text { Average } \\
\text { Standard }\end{array}$ & 119.2 & 360.7 \\
\hline & & & & Deviation & 16.8 & 47.1 \\
\hline \multirow{5}{*}{220} & S4 & 40 & 21.3 & 898.6 & 122.9 & 344.8 \\
\hline & S5 & 40 & 21.3 & 898.6 & 88.4 & 248.1 \\
\hline & S6 & 40 & 21.3 & 898.6 & 149.2 & 418.7 \\
\hline & & & & $\begin{array}{l}\text { Average } \\
\text { Standard }\end{array}$ & 120.2 & 337.2 \\
\hline & & & & Deviation & 24.9 & 69.9 \\
\hline
\end{tabular}

\subsection{Test Set-Up and Instrumentation}

The drop hammer test procedure was employed for the dynamic testing of FRP bars. The drop hammer set-up, depicted in Fig. 1, had a maximum impact velocity and maximum kinetic energy of $10 \mathrm{~m} / \mathrm{s}$ and $2.5 \mathrm{~kJ}$, respectively. One end of the bar was braced using artificial clay to prevent its slippage. The testing machine is equipped with a $20 \mathrm{t}$ dynamic load cell, that measures the axial load applied to the bar specimens and a laser displacement transducer, to measure the deflection of the bars. The load cell and displacement transducer were both connected to a data acquisition unit, monitored by a computer. The acquisition system recorded the applied load and displacement data in a coordinated manner, with the aid of photocells. The acquisition of the data begins simultaneously once the suspended hammer is released from the predefined height, up until the hammer hits the bar with a specific velocity. 


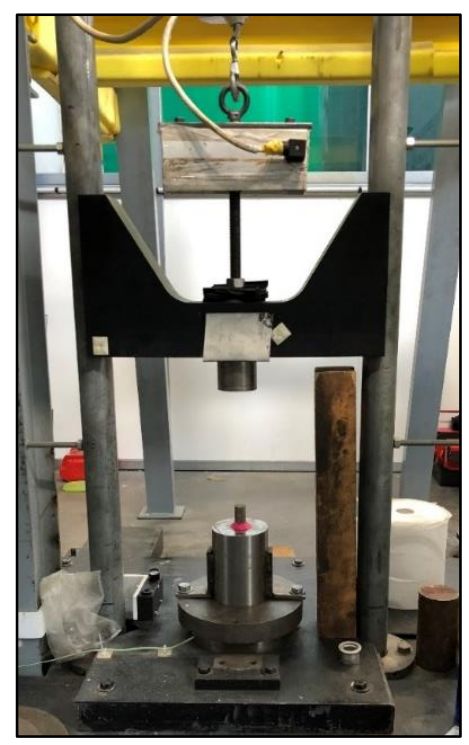

Fig. 1. Apparatus used for the dynamic tests of the BFRP bars.

\section{Experimental Results and Discussion}

The relationship between the maximum stress achieved by the FRP bars and the loading rate is depicted in Fig. 2. From the graphs, it can be deduced that the increase in loading rates caused an increase in the ultimate stress for B0-D20 and B1-D20 (Fig. 2a and 2c). However, the increase in the loading rate caused a drop in the B1-D17 group maximum stress, shown in Fig. 2b. The B0-D20 group reported the lowest maximum stress value of $170.4 \mathrm{MPa}$ for a loading rate of $217 \mathrm{~s}^{-1}$. On the other hand, the highest stress value, $419.8 \mathrm{MPa}$, was reported for B1-D17 bars at a loading rate of $175 \mathrm{~s}^{-1}$.

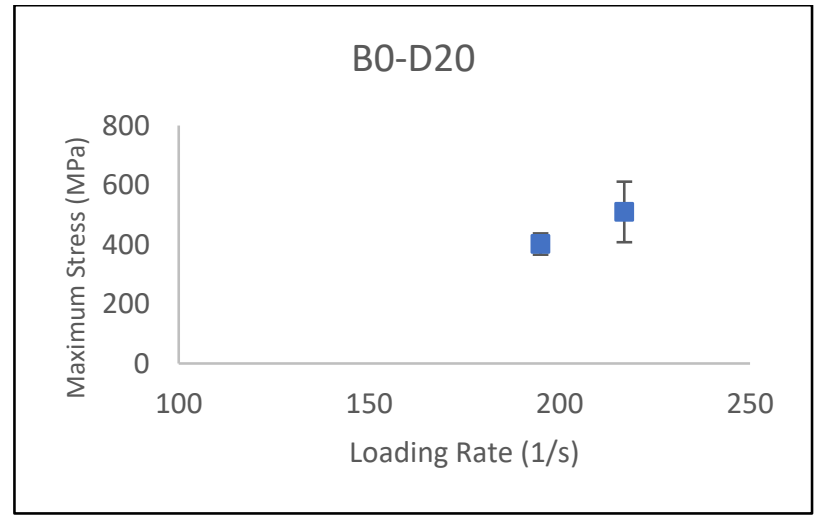

(a) 


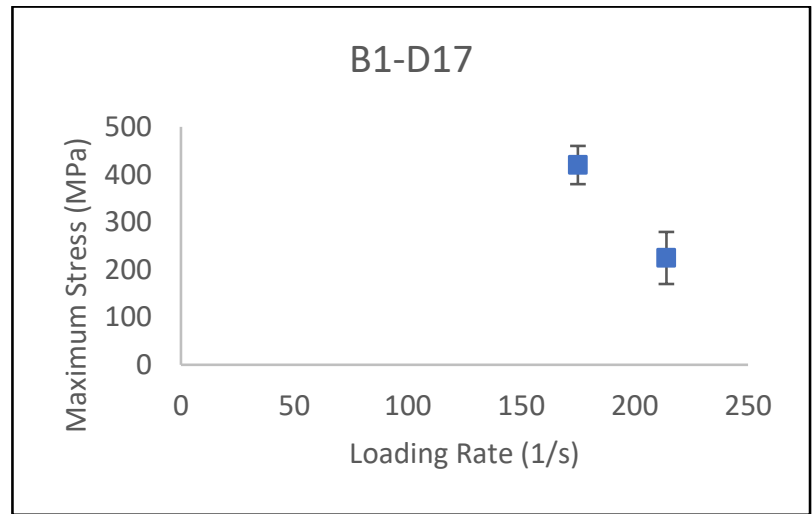

(b)

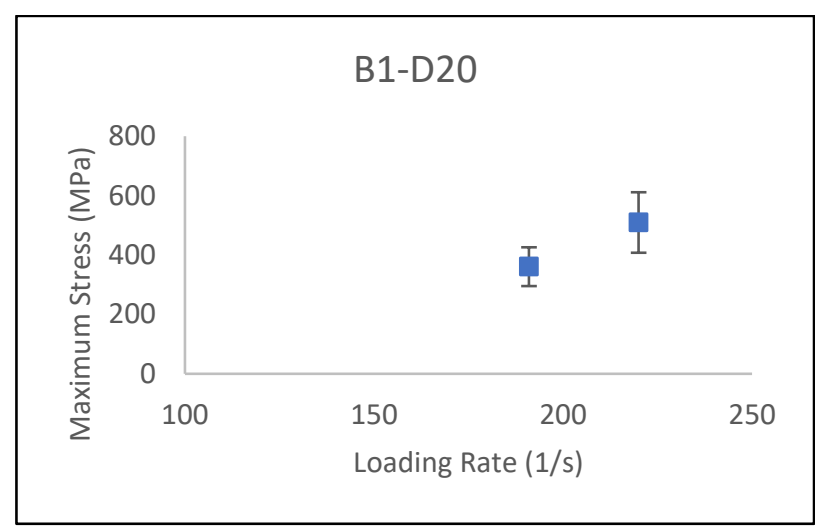

(c)

Fig. 2. Confidence Interval Graphs of (a) B0-D20 (b) B1-D17 (c) B1-D20

Figs. 3 and 4 show the failure modes of the BFRP bars. Most specimens exhibited a conical shape after failure, where the separation of the fibers was prominent in the free end of the bar, shown in Fig. 3. Other specimens crushed completely, as depicted in Fig. 4.

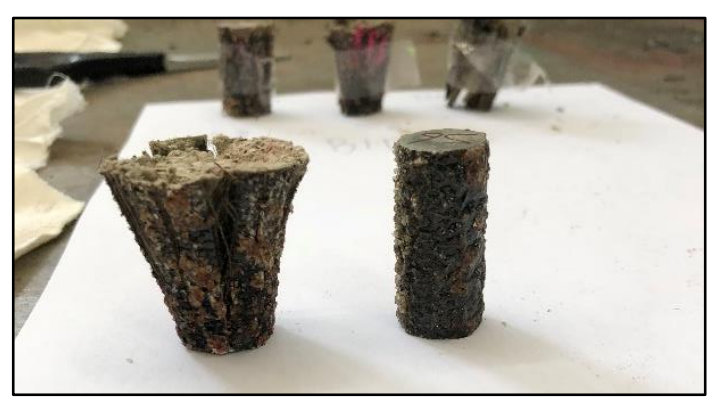

Fig. 3. BFRP bars with conical shape 


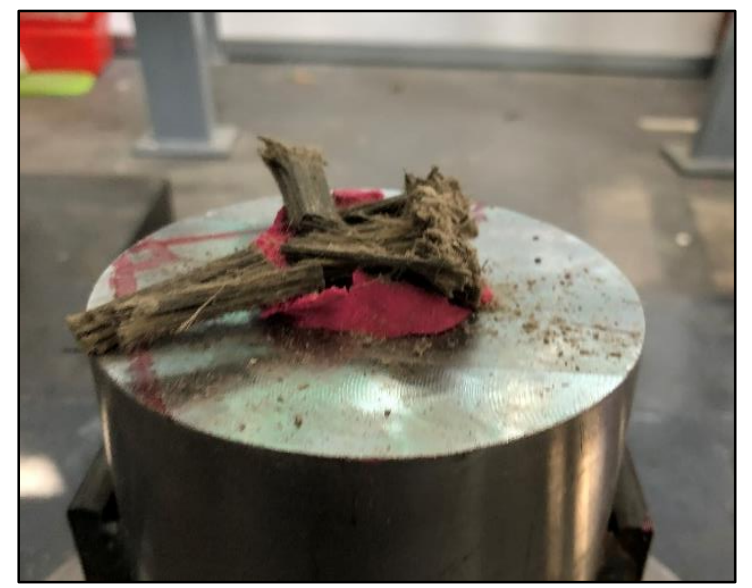

Fig. 4. BFRP bars crushed completely

\section{Conclusion}

This study aims to investigate the dynamic response of BFRP bars to impact loading by adopting the drop hammer test. The paper reports the results of 15 bars with different diameters tested under various loading rates. Based on the experimental results, the lowest and highest maximum stress values (170.4 MPa and 419.8 MPa) were reported by B0-D20 and B1-D17 bars, respectively. The B0-D20 and B1-D20 groups showed an increase in maximum stress with the increase in rates of loading. The strength value of the B1-D17 bars dropped as the loading rate increased, which requires additional investigation. Most specimens failed in a conical manner, whereas others were crushed completely.

\section{References}

1. A. Altalmas, A. El Refai and F. Abed, Const. Build. Mat., 81, 162-171 (2015)

2. A. El Refai, F. Abed and A. Altalmas,, J. Comp. Const., 19, 04014078 (2016)

3. A. Al-Tamimia, F. Abed and A. Al-Rahmani, Adv. Conc. Const., 2, pp. 1-11 (2014)

4. A. El Refai, F. Abed, and A. Al-Rahmani, Const. Build. Mat., 96, pp. 518-529 (2015)

5. A. El Refai and F. Abed, J. Comp. Const., 20, p. 04015082 (2016)

6. F. Abed, H. El-Chabib, and M. AlHamaydeh, J. Rein. Plas. Comp.,31, pp. 1063-1073 (2012)

7. F. Abed, A. El Refai and S. Abdalla, Struc.,20, pp. 689-701 (2019)

8. CAN/CSA S806, "Design and Construction of Building Structures with FibreReinforced Polymers," Canadian Standards Association, Mississauga, Ontario (2012)

9. ACI 440.1R, "Guide for the Design and Construction of Structural Concrete Reinforced Fiber-Reinforced Polymer (FRP) Bars," American Concrete Institute, Farmington Hills, MI (2015) 
10. N. ElMessalami, A. El Refai and F. Abed, Const. Build. Mat., 209, pp. 725-737 (2019)

11. K. Khorramian and P. Sadeghian, J. Test. Eval., 49, p. 20180873 (2019)

12. Q. S. Khan, M. N. Sheikh, and M. N. Hadi Available:https://scholars.uow.edu.au/display/publication104740.

13. D. Deitz, I. Harik, and H. Gesund, J. Comp. Const.,, 7, pp. 363-366 (2003)

14. E. Bruun, Can. Y. Sci. J., 2014, pp. 22-29 (2014)

15. P. Thiyagarajan, V. Pavalan, and R. Sivagamasundari, Int. J. App. Eng. R., 13, pp. 58585862 (2018)

16. H. Tobbi, A. Farghaly and B. Benmokrane, ACI Str. J.,109, pp. 551-558, (2012)

17. C. Choo, I. Harik and H. Gesund, , ACI Str. J., 103, pp. $452-459$ (2006)

18. M. Goldston, A. Remennikov and M. Sheikh, , Eng. Str., 113, pp. 220-232 (2016)

19. S. Roudsari, S. Hamoush, S. Soleimani, T. Abu-Lebdeh and M. HaghighiFar, , A. J. Eng. App. Sci., 11, pp. 407-425 (2018) 